about 5 per cent of the population of $T$. martini in each test does not swarm and is lost in subsequent transfers. Suspensions of 50-100 thousand nematodes of 70-80 per cent T. martini have been purified in two serial swarmings to more than 99 per cent T. martini, with a virtual elimination of organic and mineral debris. Factors which stimulate swarming include a high proportion of active $T$. martini in the mixed population and a suspension density such that the individual nematodes of this species are in contact in a shallow aqueous layer. A range of room temperatures and of water reactions varying from $p \mathrm{H} 3 \cdot 5$ to $7 \cdot 5$ have not influenced swarming intensity.

Department of Plant Pathology, JOHN P. HOLLIS

Louisiana State University,

Baton Rouge, Louisiana. Aug. 5.

\section{Cardiac Glycosides and Thyroidal lodide Transport}

DURING the past few years, it has become apparent that an important action of the cardiac glycosides involves the transport of potassium ions into the cell. It has also become possible, by the use of potassiumdepleted erythrocytes, to test the relative inhibitory potency of such glycosides or their aglycones in vitro $^{2}$. Approximately 80 per cent of the potassium influx can be inhibited by the glycoside by an action that appears to involve competition by drug and potassium ions for the active transport site. The transport of chloride ions in the stomach appears to be similarly affected ${ }^{3}$. Since the maintenance of a concentration gradient for iodide by an 'active transport' is one of the fundamental properties of thyroid tissue, we determined whether or not iodide transport was likewise inhibited by the cardiac glycosides.

Sheep thyroid slices $(\sim 150 \mathrm{mgm}$.) were incubated for $70-90$ minutes at $37^{\circ} \mathrm{C}$. in Krebs-Ringer phosphate medium (3 ml.), $p \mathrm{H} 7 \cdot 4$, containing $10^{-3} M$ 1-methyl-2-mercaptoimidazole, to block organic iodine formation, and $0 \cdot 2-0 \cdot 3 \mu \mathrm{c}$. of carrier-free iodine-131. The iodine-127 content varied from 0.15 to $0.20 \mu \mathrm{gm}$. per $100 \mathrm{ml}$. Cardiac glycosides were dissolved in absolute ethanol, diluted with water and added to the flasks as $0 \cdot 1$ of the final volume to yield a final ethanol concentration of 1-2 per cent. Controls received equivalent quantities of ethanol. Results are expressed as the ratio of jodine-131 content per gram of tissue to the iodine-131 content per $\mathrm{ml}$. of medium ( $T / M$ ratio).

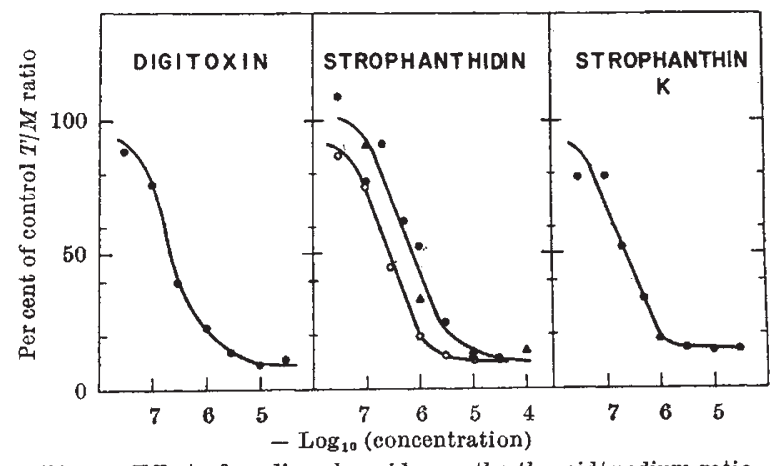

Fig. 1. Effect of cardiac glycosides on the thyroid/medium ratio (T/M ratio) of iodine-131 in sheep thyroid slices. The control $T / M$ ratios varied from $12-25:$ and $A$, experiments 1 and
fltting approximately the same curve; $O$, experiment 3
Table 1. Inhibition”of Iodide Transport by Cardiad Guycosides

\begin{tabular}{|c|c|c|}
\hline \multirow[b]{3}{*}{$\begin{array}{l}\text { Digitoxin } \\
\text { Strophanthidin } \\
\text { Strophanthin } K\end{array}$} & \multicolumn{2}{|c|}{$\begin{array}{c}\text { Concentration for } 50 \text { per cent inhibition } \\
\text { of the } T / M \text { ratio* }(M)\end{array}$} \\
\hline & Sheep thyroid slices & Rat tumour slices \\
\hline & $\begin{array}{r}2 \times 10^{-7} \\
2-5 \times 10^{-7} \\
2 \times 10^{-7}\end{array}$ & $\begin{array}{r}1.5 \times 10^{-4} \\
9 \times 10^{-4}\end{array}$ \\
\hline
\end{tabular}
Incubated at $37^{\circ} \mathrm{C}$. unde
$7 \cdot 4$, for $70-90 \mathrm{~min}$.

The results, depicted in Fig. 1, demonstrate that two glycosides, digitoxin and strophanthin $K$, as well as the aglycone strophanthidin, all depress the $T / M$ at concentrations comparable to those found to inhibit potassium transport. For strophanthidin, the results of three separate runs show the variation in responsiveness that occurs between different batches of glands. The inhibitory potency of the drugs can be compared at the point of 50 per cent inhibition (Table 1). The order compares more closely with that of Solomon et al. ${ }^{2}$ than that of Kahn and Acheson'. The concentrations for 50 per cent inhibition are probably somewhat lower, since the curves do not go below 10 per cent of the control $T / M$ value (Fig. I).

We have recently described a thyroid tumour in rats in which the iodide-concentrating mechanism survived without the further steps in hormone synthesis ${ }^{4}$. As shown in Table 1, the iodide concen. trating mechanism of these tumours is about 1,000 fold less sensitive to the cardiac glycosides than is normal sheep thyroid tissue. Another tissue that normally maintains an iodide gradient is the submaxillary gland of mice ${ }^{5}$. Preliminary experiments with submaxillary glands of $C 3 H$ mice have yielded variable results : no inhibition at $10^{-4} M$ strophanthidin and 30 per cent inhibition with $10^{-4} M$ digitoxin. We were, however, not able to obtain mice with salivary $T / M$ ratios as high as those previously reported.

The above results indicate that thyroid tissue transports iodide by a system that is sensitive to inhibition by the cardiac glycosides. The kinetics of the inhibition and the relation of iodide to potassium transport are now under investigation.

We should like to thank Dr. J. E. Rall for his advice during the course of this work, and I. L. Cooperstein for permitting us to see the manuscript of ref. 3 prior to publication.

\section{J. WOLFF}

J. R. MAUREY

National Institute of Arthritis and Metabolic Diseases,

National Institutes of Health, Bethesda, Maryland.

${ }^{1}$ Kahn, J. B., and Acheson, G. H., J. Pharm. Exp. Therap., 115, 305 $(1957)$.

2 Solomon, A. K., Gill, T. J., and Gold, G. L., J. Gen. Physiol., 40, 32 ' (1956).

${ }^{3}$ Cooperstein, I. L. (to be published).

4 Wolff, J., Robbins, J., and Rall, J. E., Endocrinol. (in the press).

s Fletcher, K., Honour, A. J., and Rowlands, E. N., Biochem. J., 63, 194 (1956).

\section{Spontaneous Electrical Activity in the Denervated Muscles of the Cockroach Periplaneta americana}

Speciar features of the anatomy and physiology of the invertebrate neuromuscular junction raise the question of to what extent the changes caused by denervation of the insect muscles are analogous to those in the denervated museles of vertebrates. 